\title{
Myocardial expression profiles of candidate molecules in patients with arrhythmogenic right ventricular cardiomyopathy/dysplasia compared to those with dilated cardiomyopathy and healthy controls
}

Akdis, Deniz ; Medeiros-Domingo, Argelia ; Gaertner-Rommel, Anna ; Kast, Jeannette I ; Enseleit, Frank ; Bode, Peter ; Klingel, Karin ; Kandolf, Reinhard ; Renois, Fanny ; Andreoletti, Laurent ; Akdis, Cezmi A ; Milting, Hendrik ; Lüscher, Thomas F ; Brunckhorst, Corinna ; Saguner, Ardan M ; Duru, Firat

\begin{abstract}
BACKGROUND Arrhythmogenic right ventricular dysplasia/cardiomyopathy (ARVC/D) is a mainly autosomal-dominant disease characterized by fibrofatty infiltration of the right ventricle leading to ventricular arrhythmias. Mutations in desmosomal proteins can be identified in about half of the patients. The pathogenic mechanisms leading to disease expression remain unclear. OBJECTIVE To investigate myocardial expression profiles of candidate molecules involved in the pathogenesis of ARVC/D. METHODS Myocardial mRNA expression of 62 junctional molecules, five cardiac ion channel molecules, eight structural molecules, four apoptotic molecules and six adipogenic molecules was studied. The averaged expression of candidate mRNAs between ARVC/D samples $(\mathrm{n}=10)$, non-familial dilated cardiomyopathy $(\mathrm{DCM})$ samples $(\mathrm{n}=10)$ and healthy control samples $(\mathrm{n}=8)$ were compared. Immunohistochemistry and quantitative protein expression analysis was performed. Genetic analysis using next-generation sequencing was performed in all ARVC/D patients. RESULTS Following mRNA levels were significantly increased in ARVC/D compared to DCM and controls: phospholamban ( $\mathrm{p}=<0.001$ vs DCM; $\mathrm{p}=<0.001$ vs controls), tumor protein 53 apoptosis effector (PERP) ( $\mathrm{p}=0.001$ vs DCM; $\mathrm{p}=<0.001$ vs controls), and carnitine palmitoyltransferase 1 beta $(\mathrm{CPT} 1 \mathrm{~B})(\mathrm{p}=<0.001$ vs DCM; $\mathrm{p}=0.008$ vs controls). Plakophillin- 2 (PKP-2) mRNA was downregulated in ARVC/D patients with PKP-2 mutations compared to ARVC/D patients without PKP-2 mutations $(\mathrm{p}=0.04)$. Immunohistochemistry revealed significantly increased protein expression of phospholamban, PERP and CPT1B in ARVC/D patients, and decreased PKP-2 expression in ARVC/D patients carrying a PKP-2 mutation. CONCLUSIONS Changes in the expression profiles of sarcolemmal calcium channel regulation, apoptosis and adipogenesis suggest that these molecular pathways may play a critical role in the pathogenesis of ARVC/D, independent of underlying genetic mutations.
\end{abstract}

DOI: https://doi.org/10.1016/j.hrthm.2015.11.010

Posted at the Zurich Open Repository and Archive, University of Zurich ZORA URL: https://doi.org/10.5167/uzh-115065

Journal Article

Accepted Version 
The following work is licensed under a Creative Commons: Attribution-NonCommercial-NoDerivatives 4.0 International (CC BY-NC-ND 4.0) License.

Originally published at:

Akdis, Deniz; Medeiros-Domingo, Argelia; Gaertner-Rommel, Anna; Kast, Jeannette I; Enseleit, Frank; Bode, Peter; Klingel, Karin; Kandolf, Reinhard; Renois, Fanny; Andreoletti, Laurent; Akdis, Cezmi A; Milting, Hendrik; Lüscher, Thomas F; Brunckhorst, Corinna; Saguner, Ardan M; Duru, Firat (2016). Myocardial expression profiles of candidate molecules in patients with arrhythmogenic right ventricular cardiomyopathy/dysplasia compared to those with dilated cardiomyopathy and healthy controls. Heart Rhythm, 13(3):731-741.

DOI: https://doi.org/10.1016/j.hrthm.2015.11.010 


\section{Author's Accepted Manuscript}

Myocardial Expression Profiles of Candidate Molecules in Arrhythmogenic Right Ventricular Cardiomyopathy/Dysplasia compared to Dilated Cardiomyopathy and Healthy Controls

Deniz Akdis MD, Argelia Medeiros-Domingo MD, Anna Gaertner-Rommel MD, Jeannette I. Kast MSc, Frank Enseleit MD, Peter Bode MD, Karin Klingel MD, Reinhard Kandolf MD, Fanny Renois PhD, Laurent Andreoletti MD, Cezmi A. Akdis MD, Hendrik Milting $\mathrm{PhD}$, Thomas F. Lüscher MD, Corinna Brunckhorst MD, Ardan M. Saguner MD, Firat Duru MD

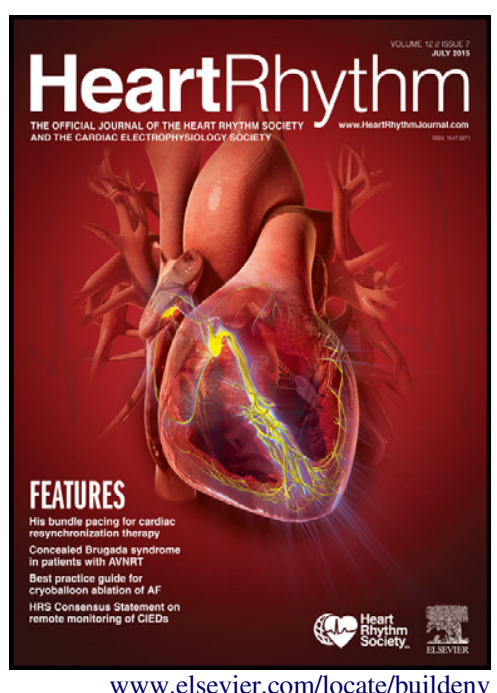

www.elsevier.com/locate/buildenv

PII:

S1547-5271(15)01396-X

DOI: http://dx.doi.org/10.1016/j.hrthm.2015.11.010

Reference: HRTHM6501

To appear in: Heart Rhythm

Cite this article as: Deniz Akdis MD, Argelia Medeiros-Domingo MD, Anna GaertnerRommel MD, Jeannette I. Kast MSc, Frank Enseleit MD, Peter Bode MD, Karin Klingel MD, Reinhard Kandolf MD, Fanny Renois PhD, Laurent Andreoletti MD, Cezmi A. Akdis MD, Hendrik Milting PhD, Thomas F. Lüscher MD, Corinna Brunckhorst MD, Ardan M. Saguner MD, Firat Duru MD, Myocardial Expression Profiles of Candidate Molecules in Arrhythmogenic Right Ventricular Cardiomyopathy/Dysplasia compared to Dilated Cardiomyopathy and Healthy Controls, Heart Rhythm, http://dx.doi.org/10.1016/ j.hrthm.2015.11.010

This is a PDF file of an unedited manuscript that has been accepted for publication. As a service to our customers we are providing this early version of the manuscript. The manuscript will undergo copyediting, typesetting, and review of the resulting galley proof before it is published in its final citable form. Please note that during the production process errors may be discovered which could affect the content, and all legal disclaimers that apply to the journal pertain. 
Original article - Revision

\title{
Myocardial Expression Profiles of Candidate Molecules in Arrhythmogenic Right Ventricular Cardiomyopathy/Dysplasia compared to Dilated Cardiomyopathy and Healthy Controls
}

\author{
Short title: Novel Molecules in ARVC/D
}

Deniz Akdis MD ${ }^{a}$, Argelia Medeiros-Domingo MD ${ }^{a, d}$, Anna Gaertner-Rommel MD ${ }^{c}$, Jeannette I Kast MSc ${ }^{b}$, Frank Enseleit MD ${ }^{a}$, Peter Bode MD ${ }^{e}$, Karin Klingel MD ${ }^{f}$, Reinhard Kandolf $\mathrm{MD}^{\mathrm{f}}$, Fanny Renois $\mathrm{PhD}^{\mathrm{g}}$, Laurent Andreoletti $\mathrm{MD}^{\mathrm{g}}$, Cezmi $\mathrm{A}$ Akdis $\mathrm{MD}^{\mathrm{b}}$, Hendrik Milting $\mathrm{PhD}^{\mathrm{c}}$, Thomas $\mathrm{F}$ Lüscher $\mathrm{MD}^{\mathrm{a}, \mathrm{h}}$, Corinna Brunckhorst $\mathrm{MD}^{\mathrm{a}}$, ${ }^{*}$ Ardan M Saguner MDa , *Firat Duru MD ${ }^{\mathrm{a}, \mathrm{h}}$

\begin{abstract}
${ }^{a}$ Department of Cardiology, University Heart Center Zurich, Switzerland; ${ }^{b}$ Swiss Institute of Allergy and Asthma Research (SIAF), University of Zurich, Davos, Switzerland; 'Heart and Diabetes Center NRW, Ruhr University

Bochum, Bad Oeynhausen, Germany; 'Department of Cardiology, University Hospital Bern, Switzerland;

e Department of Pathology, University Hospital Zurich, Switzerland; 'Department of Molecular Pathology, University Hospital Tübingen, Germany; ' Laboratoire de Virologie Médicale et Moléculaire, EA 4684 CardioVir, Faculté de Médecine et CHU Robert Debré, Reims, France; ${ }^{\mathrm{h}}$ Center for Integrative Human Physiology, University of Zurich, Switzerland
\end{abstract}

${ }^{*}$ AMS and FD contributed equally to this article and are shared senior authors

Correspondence:

Prof. Dr. Firat Duru

Department of Cardiology

University Heart Center Zurich

Rämistrasse 100,

$\mathrm{CH}-8091$ Zurich Switzerland

E-mail: firat.duru@usz.ch

Telephone: + 41442552099

Fax: +41442554401

There are no conflicts of interest declared by none of the authors

\section{Abstract}

Background: Arrhythmogenic right ventricular dysplasia/cardiomyopathy (ARVC/D) is a mainly autosomal-dominant disease characterized by fibrofatty infiltration of the right 
ventricle leading to ventricular arrhythmias. Mutations in desmosomal proteins can be identified in about half of the patients. The pathogenic mechanisms leading to disease expression remain unclear.

Objective: To investigate myocardial expression profiles of candidate molecules involved in the pathogenesis of ARVC/D.

Methods: Myocardial mRNA expression of 62 junctional molecules, five cardiac ion channel molecules, eight structural molecules, four apoptotic molecules and six adipogenic molecules was studied. The averaged expression of candidate mRNAs between ARVC/D samples $(n=10)$, non-familial dilated cardiomyopathy $(\mathrm{DCM})$ samples $(n=10)$ and healthy control samples $(n=8)$ were compared. Immunohistochemistry and quantitative protein expression analysis was performed. Genetic analysis using next-generation sequencing was performed in all ARVC/D patients.

Results: Following mRNA levels were significantly increased in ARVC/D compared to DCM and controls: phospholamban ( $p=<0.001$ vs $D C M$; $p=<0.001$ vs controls), tumor protein 53 apoptosis effector (PERP) ( $p=0.001$ vs $\mathrm{DCM} ; \mathrm{p}=<0.001$ vs controls), and carnitine palmitoyltransferase 1 beta $(C P T 1 B)(p=<0.001$ vs DCM; $p=0.008$ vs controls). Plakophillin-2 (PKP-2) mRNA was downregulated in ARVC/D patients with PKP-2 mutations compared to ARVC/D patients without PKP-2 mutations $(p=0.04)$. Immunohistochemistry revealed significantly increased protein expression of phospholamban, PERP and CPT1B in ARVC/D patients, and decreased PKP-2 expression in ARVC/D patients carrying a PKP-2 mutation.

Conclusions: Changes in the expression profiles of sarcolemmal calcium channel regulation, apoptosis and adipogenesis suggest that these molecular pathways may play a critical role in the pathogenesis of $A R V C / D$, independent of underlying genetic mutations.

Key words: cardiomyopathy, arrhythmogenic right ventricular, dysplasia, apoptosis, adipogenesis, phospholamban

Abbreviations: Arrhythmogenic right ventricular cardiomyopathy/dysplasia (ARVC/D), dilated cardiomyopathy (DCM), fractional area change (FAC), implantable cardioverter- 
defibrillator (ICD), left ventricular ejection fraction (LVEF), right ventricular outflow tract (RVOT), sudden cardiac arrest (SCA), Task Force score (TFS), ventricular tachycardia (VT)

\section{Introduction}

Arrhythmogenic right ventricular dysplasia/cardiomyopathy (ARVC/D) is an inherited cardiomyopathy characterized by fibrofatty infiltration of myocardial tissue, especially of the right ventricle. ${ }^{1}$ The pattern of inheritance in ARVC/D is generally autosomal dominant with incomplete penetrance. Genetic studies have identified at least 13 different chromosomal loci associated with $A R V C / D$, thus reflecting a high genetic heterogeneity. ${ }^{2}$ Among them are the five major desmosomal genes [plakophilin-2 (PKP-2), desmoplakin (DSP), desmoglein-2 (DSG-2), desmocollin-2 (DSC-2), plakoglobin (JUP)], the non-desmosomal junctional gene aT-catenin3 (CTTN-A3), and seven non-junctional genes [ryanodine receptor-2 (RYR-2), transforming growth factor $\beta-3$ (TGFB3), transmembrane protein-43 (TMEM43), desmin (DES), titin (TTN), lamin A/C (LMNA), and phospholamban (PLN)]. ${ }^{2} \quad$ Nonetheless, desmosomal mutations are found in approximately half of ARVC/D patients and nondesmosomal mutations are rarely observed. ${ }^{3,4}$ ARVC/D subtypes such as the classical right ventricular form, biventricular or left ventricular dominant disease may coexist within families, which also implicates the variability of clinical phenotypes. ${ }^{1}$ The most common mutations involve the PKP2 gene, followed by mutations of the DSG-2 and DSP genes. ${ }^{2}$ In cardiomyocytes, the desmosomal cadherins DSG-2 and DSC-2, the plakin DSP, which binds to the intermediate filament DES, the linking armadillo proteins PKP-2 and JUP build desmosomal structures, which are crucial for cardiomyocyte adhesion and mechanical stability. ${ }^{5}$ Desmosomal proteins strongly interact with other junctional molecules, such as other cadherins, catenins and gap junction molecules, connexins (Cx) 40, 43 and 45. These functional formations are called connexomes, and the cardiac intercalated disc is likely the host of this complex protein-interacting network. ${ }^{6,7}$ Recent studies have shown that these intercellular formations may also play a role in signal transduction, apoptosis, and adipogenesis. ${ }^{8}$ Early histology and electron microscopy studies revealed that the fibrofatty 
replacement of the right ventricular myocardium is accompanied by inflammation and apoptosis. ${ }^{9}$ Desmosomal mutations may lead to altered cellular distribution of desmosomes, as well as increased apoptosis. ${ }^{10}$ It has been demonstrated that the tumor protein 53 apoptosis effector (PERP) does not only play a role in the initiation of apoptosis, but is also involved in desmosomal structures. ${ }^{11}$ Studies on induced pluripotent stem cells have highlighted that in the acute failing heart, carnitine-palmitoyltransferase-1beta (CPT1B), a molecule leading to mitochondrial long chain fatty acid uptake, may play an important role in fatty acid oxidation. ${ }^{12}$ TGFB3, a cytokine involved in the modulation of desmosomal proteins and stimulation of fibrosis has also been reported to have an influence on the pathogenesis of myocardial fibrosis. ${ }^{13}$ Experimental and clinical data suggest that other non-junctional cellular structures like the voltage-gated sodium channel (Nav 1.5), the sarcolemmal calcium channel regulating molecule PLN, and structural molecules are linked to desmosomes. ${ }^{14}$ Especially PLN phosphorylation has been reported to play a key role in the pathophysiology of heart failure. ${ }^{15}$ Taken together, various cellular pathways, particularly electromechanical cell-to-cell coupling, inflammation, apoptosis, adipogenesis and fibrosis seem to be involved in the pathophysiology of ARVC/D, but the interactions are not fully understood. Therefore, the aim of this study was to identify dysregulated myocardial molecules associated with the mentioned pathways ARVC/D by investigating the myocardial expression profiles of various candidate proteins using an mRNA expression and immunolocalization approach.

\section{Methods}

\section{Human myocardial tissue samples}

10 patients with a definite diagnosis of ARVC/D were included in this study (Table 1). ${ }^{16}$ In five of these, right ventricular myocardial samples were obtained by endomyocardial biopsy, in the others during transplantation. All samples were immediately placed in RNAlater ${ }^{\circledR}$ solution (Life Technologies, Zug, Switzerland), or snap frozen in liquid nitrogen and stored at $-80^{\circ} \mathrm{C}$, or formalin fixed and paraffin embedded for immunohistochemistry staining. 10 myocardial tissue samples of patients with non-familial dilated cardiomyopathy (DCM) were obtained 
during transplantation, immediately placed in RNAlater ${ }^{\circledR}$ solution, stored at $-80^{\circ} \mathrm{C}$, or formalin fixed and paraffin embedded for immunohistochemistry staining. This tissue was obtained from patients with clinical and histological diagnosis of non-ischemic DCM with no family history of DCM. In addition, autopsy specimen from six individuals, and biopsies from two individuals without heart disease, served as controls. The post-mortem interval until tissue processing was between $10 \mathrm{~h}$ and $24 \mathrm{~h}$, at $4{ }^{\circ} \mathrm{C}$, to guarantee optimal mRNA and protein preservation. ${ }^{17,18}$ Cardiac disease was excluded in these patients by clinical reports, macroscopic and histologic studies. Staining for the apoptotic protein cleaved caspase-3 was performed to investigate autopsy tissue quality. ${ }^{19}$ Autopsy samples were all taken from the right ventricular septum immediately at the beginning of the autopsy, and directly stored in RNAlater $®$ solution, or formalin fixed and paraffin embedded.

This project was conducted in full agreement with the principles of the "Declaration of Helsinki" and current Swiss law. It has been approved by the Ethics Committee of the Canton of Zurich (approval number KEK-ZH-Nr. 2014-0443). All ARVC/D patients signed an informed consent form for prospective inclusion. The ethical approval also granted retrospective investigation of transplant/autopsy tissue.

\section{Genetic Analysis}

DNA of ARVC/D patients was extracted from peripheral macrophages. Clinical exome was performed by next generation sequencing using the TrueSight One Sequencing Panel (Illumina, San Diego, USA) including 4,813 genes. First, genes associated with ARVC/D were analysed. If no mutation was identified, genes associated with similar phenotypes were included. Our cardiac panel consisted of 104 cardiac genes (Supplementary Table 1). All variants were confirmed by Sanger sequencing. ${ }^{20}$ Read alignment and local realignment of indels was performed using CLC Workbench v7.5.1(CLCBio, Aarhus, Denmark). Variant prediction was done using the tools Polyphen2, SIFT and Mutation Taster. The following databases were used to analyze the sequences in detail: Human Gene Mutation Database 
(Biobase, Wolfenbuettel, Germany), 1000 Genoms Project (Massachusetts, USA) and Exome Aggregation Consortium browser (ExAC).

\section{mRNA expression analysis using Taqman ${ }^{\circledR}$ low density array microfluidic cards}

mRNA extraction was performed using the RNeasy mini kit with Trizol (Quiagen, Hilden, Germany). 400ng of total RNA was reverse transcribed using random primers (Fermentas, Hilden Germany). mRNA was measured with TaqMan® low density array micro fluidic cards using the Gene Expression Assay protocol (Applied Biosystems, Zug, Switzerland). A total of 62 junctional, 5 ion channel, 8 structural 4 apoptotic and 6 adipogenic, molecule mRNAs were investigated; each reaction was conducted as triplicates. These predesigned primers were spanning an exon-exon junction and amplified a maximal amplicon length of $200 \mathrm{nt}$. Two housekeeping genes glyceraldehyde-3-phosphate-dehydrogenase and 18srRNA were taken as individual references to adjust and normalize each primer RNA, the more stable housekeeping gene was used for data calculation. mRNA measurement was performed with 7900HT fast real-time PCR system (Applied Biosystems, Zug, Switzerland). Arbitrary units $(A U)$ were calculated according to the delta cycle of threshold (ct) method: $A U=2^{(-\Delta c t)} \times 1000$. Higher AU represented higher mRNA expression, and AU between 0-5 was considered as very low or no expression. ${ }^{21}$ All mRNA data is presented in Supplementary Table 2.

\section{Immunohistochemistry and confocal microscopy}

Formalin fixed and paraffin embedded tissue samples were cut into $5 \mu \mathrm{m}$ sections. Deparaffinization was conducted using xylol and isopropanol. Slides were then cooked in citrate buffer for antigen retrieval and blocked with $10 \%$ goat serum. Overnight incubation was performed with primary antibodies anti PLN Met1-Leu52 (Cloud-Clone Corporation, Houston, Texas, USA), anti-phosphorylated PLN phosphorylation site of serin16 and threonin 17 (Bioss, Massachusetts, USA), anti-PERP (Antibodies Online, Aachen, Germany), antiCPT1B (Assay Biotech, Sunnyvale, USA), anti-PKP-2 (Bioss, Massachusetts, USA), anticleaved Caspase3 (CASP-3) (Antibodies Online, Aachen, Germany) and respective isotype 
controls (Life Technologies, Zug, Switzerland). After labelling with secondary antibodies (Alexa Fluor $488 \circledast$ ) samples were fixated with $1 \%$ paraformaldehyde and covered with ProLong ${ }^{\circledR}$ Gold Antifade Reagent with 4',6-diamidino-2-phenylindole (DAPI) (Life Technologies, Zug, Switzerland). Tissue sections were imaged with the Leica TCS SPE (Leica Microsystems, Heerbrugg, Switzerland). Protein signal intensities were quantified relatively to control healthy tissue samples using Image $\mathrm{J}$ software. This software has been validated for image analysis that allows quantification of total tissue fluorescence. ${ }^{22}$ Relative signal intensities were measured by two independent investigators blinded to the clinical data. The results were validated by another blinded observer.

\section{Data analysis}

Statistical analysis was performed using GraphPad Prism 5.0. Values are given as mean \pm standard error (SEM) or standard deviation (SD). Statistical comparison between the three groups (ARVC/D, DCM, control) was performed using the Mann-Whitney $U$ test. Statistical significance was assumed for $p$ values $<0.05$.

\section{Results}

\section{Patient characteristics}

Clinical characteristics of ARVC/D patients are presented in Table 1. All patients had definite diagnosis of ARVC/D according to the 2010 Task Force criteria. They all displayed a typical clinical ARVC/D phenotype of right or beginning biventricular heart disease, and presented with arrhythmias from the right ventricle or arrhythmogenic syncope. None of these ARVC/D patients had relevant co-morbidities. These ARVC/D patients were compared with patients with non-familial DCM (Table 1 and supplementary Table 3). All DCM patients had a clinical and histological diagnosis of DCM but no right ventricular involvement. None of the DCM patients had ischemic, toxic or hypertensive origin of DCM, and none of them had a family history of DCM. All DCM tissue was tested for enterovirus, adenovirus, parvovirus b19, 
human herpesvirus 6, herpes simplex virus 1/2, Epstein-Barr virus, human cytomegalovirus, varicella zoster virus, influenza virus, and borrelia burgdorferi and toxoplasma gondii. In three patients a viral origin was assumed, in the remaining idiopathic DCM was suspected.

\section{Genetic mutations}

All genetic variants and mutations found in our cases are listed in Table 2. Patient 1 hosted a heterozygous DSP nonsense mutation. Patient 2 carried a heterozygous DSP missense mutation. Patient 3 hosted a heterozygous DSP mutation and a homozygous DSG-2 variant. Patient 5 hosted a TTN mutation and patient 6 a RYR-2 mutation both of unknown clinical significance. Patient 7 exhibited digenic heterozygosity. His mother, who had a definite diagnosis of ARVC/D and died of SCA, harboured the same PKP2 mutation, which has been reported to alter protein function according to genetic databases (SIFT, Polyphen2, Mutation Tester). Patients 8, 9 and 10 carried nonsense mutations resulting in a premature stop codon or frameshift mutations in the PKP-2 gene. No causative mutation was identified in one patient, although he fulfilled a definite clinical phenotype.

\section{mRNA expression of molecules associated with cellular junctions}

Various junctional molecules were screened previously, to assess their mRNA expression in the healthy human heart (Supplementary Figure 1). Based on that data, and on our results from the genetic analysis, desmosomal and junctional molecules were primarily investigated in this study. With regard to desmosomal and gap junction molecules (Figure 1A), we investigated DSP, JUP, PKP-2, PKP-4, DSC-2, DSG-2, Cx40, Cx43, and Cx45 mRNAs. There was no significant difference in mRNA expression of desmosomal and gap junction molecules between ARVC/D, DCM and control tissue. Within the whole mRNA panel, from the claudin family, the claudins (CLDN) $-5,-11,-12,-14,15$, and claudin domain containing protein-1 (CLDND-1) were expressed in myocardial tissue but overall, claudin expression was very low. Compared to DCM tissue and healthy controls, there was no significant difference in patients with ARVC/D (Figure 1B). The myocardial expression of junction 
associated molecules was also assessed (Figure 1C). CTNN-A3, catenin beta 1 (CTNN-B1), membrane associated guanylate kinase (MAGI)-1 and-3, CXADR-like membrane protein (CLMP), InaD-like (INADL), cingulin (CGN), paracingulin (CGNL-1), junctional adhesion molecules (JAM) -1, -2 and -3 , and ZO-1 and -2 did not show any significant differences in mRNA expression between the three groups.

mRNA expression of molecules associated with ion channels and cellular structures

In a further step, we investigated dysregulations in other cellular pathways, since ARVC/D causing mutations have also been reported in ion channels and structural molecules. ${ }^{2}$ From the ion channel molecules, the calcium channel regulating protein PLN showed a significantly higher mRNA expression in ARVC/D compared to DCM and control hearts, but no difference between controls and DCM (Table 3A). There was no significant difference in RYR2, nav 1.5, striatin (STRN) and ankyrin-g (ANK-G) expression (Figure 2A). From the structural molecules, we screened DES, TTN, plectin (PLEC), laminin alpha (LAMA) -2 and -4, transmembrane protein (TMEM) 43 and 234, and TGFB3 (Figure 2B), but we did not find any significant differences between the three groups.

\section{mRNA expression of molecules regulating apoptosis and adipogenesis}

Molecules involved in apoptosis and adipogenesis were also investigated, since these cellular pathways have been reported to be linked to pathophysiologic mechanisms in ARVC/D. ${ }^{12,23}$ Expression levels of the proapoptotic molecules PERP, tumor protein 63 (TP63), CASP-3 and the antiapoptotic molecule B-cell-lymphoma-2 (BCL-2) were assessed (Figure 2C). PERP mRNA expression was significantly higher in ARVC/D compared to DCM and controls (Table 3A), while BCL-2, CASP-3, and TP63 did not differ between the 3 groups. Further, we investigated adipogenic molecules, such as fatty acid binding protein 4 (FABP4), peroxisome proliferator-activated receptor (PPAR) $\alpha, \delta$ and $\gamma$, CPT1B, and LMNA (Figure 2B). While CPT1B mRNA expression was significantly increased in ARVC/D compared to DCM and controls (Table 3A), the other adipogenic molecules did not differ 
between groups. We also measured mRNA expression of common inflammatory cytokines interferon- $\alpha, \beta$ and $\gamma$, tumor necrosis factor, interleukin- 6 and the antiinflammatory interleukin10. These molecules had no detectable expression in ARVC/D, DCM and controls.

\section{mRNA and protein expression in ARVC/D patients with pathogenic PKP2 mutations}

Since, in most cohorts, PKP-2 mutations are the most common genetic cause of ARVC/D, we performed sub analyses of mRNA expression in patients with PKP2 mutations in our cohort. We were able to demonstrate that mRNA expression of PLN and PERP was significantly increased in this cohort. The mRNA level of CPT1B was significantly increased compared to DCM tissue, and showed a trend towards increased levels compared to controls (Figure 3A, Table 3B).

Furthermore, the mRNA expression of PKP-2 was decreased in ARVC/D patients with PKP-2 mutations compared to those without (Figure 3B). This was also true for protein expression, where the relative signal intensity of PKP2 was decreased in ARVC/D patients with PKP-2 mutations compared to ARVC/D patients without PKP-2 mutations but the localization inside intercalated discs was the same (Figure $3 \mathrm{C}$ and D).

Protein expression and localization of PLN, PERP, CPT1B and apoptotic marker cleaved CASP3

Immunostaining was used to visualize and semi-quantify protein levels of significantly dysregulated mRNAs. PLN, PERP and CPT1B were all located intracellularly, and protein expression was significantly higher in ARVC/D compared to DCM and controls (Figure 4A). We measured protein intensity of total PLN and found significantly higher levels in ARVC/D compared to the other groups (ARVC/D versus DCM: $p=0.03 ; A R V C / D$ versus controls: $p=$ 0.03), but no difference between DCM and controls. To gain further insights, we also assessed protein intensity of phosphorylated PLN (pPLN), and found a highly significant upregulation in ARVC/D patients, compared to DCM and controls (ARVC/D versus DCM: $p=0.003 ; A R V C / D$ versus controls: $p=0.02$. PERP and CPT1B protein intensity were also 
increased in ARVC/D compared to $\mathrm{DCM}$ ( $p=0.01$ and $p=0.006$, respectively) and controls $(p=0.002$ and $p=0.03$, respectively). PERP expression was higher in DCM than controls $(p=0.02)$ (Figure 4B). To visualize and compare apoptosis, we located cleaved CASP3 on healthy cardiac biopsy and autopsy tissue, and also on ARVC/D and DCM tissue. These experiments did not show any significant differences in protein signal intensity in all four groups (Supplementary figure 2).

\section{Discussion}

This study has several major findings: we show for the first time that in patients with ARVC/D an increased mRNA expression translates into a higher protein expression of PLN, an intracellular ion channel receptor molecule linked to the intercalated disc, and of PERP and CPT1B, two molecules involved in apoptosis and adipogenesis. Our findings indicate that the upregulation of certain proteins involved in ion channels, apoptosis and adipogenesis may play a common role in the pathogenesis of ARVC/D, independent of underlying mutations. These findings suggest that, although there is a great variability in involved genes and clinical disease expression, there may be some common pathways involved in the pathogenesis of ARVC/D. In addition, PKP-2 mRNA and protein expression may differ among ARVC/D patients depending on the underlying mutation.

\section{Desmosomal molecules}

A complex network of molecular interactions that involve junctional molecules inside intercalated discs is currently considered to underlie the pathophysiology of ARVC/D. Cell junctions, intracellular structures linked to the area composita, ion channels, apoptosis, and adipogenesis are likely to play an important part. ${ }^{2}$ Recent studies highlight that desmosomal mutations may lead to a remodelling inside the area composita and a defective distribution of ion channel molecules, but not necessarily to decreased levels of other desmosomes in general. ${ }^{24}$ In line with those studies, our analysis revealed that in patients with ARVC/D, there is no general decrease in all desmosomal mRNAs, but that pathogenic desmosomal 
nonsense or frameshift mutations may lead to decreased levels of those particular desmosomal molecules. ${ }^{25,26}$

\section{Phospholamban}

PLN is a protein linked to the sarcoplasmatic reticulum, inhibiting the calcium intake when dephosphorylated, and increasing myocardial contractility through calcium intake when phosphorylated. Although PLN is a major determinant of cardiac contractility and relaxation, it remains controversial whether heart failure leads to decreased PLN levels or vice versa, and whether the amount of phosphorylation may differ. It has been shown that decreased phosphorylation of PLN, and an increase of the PLN to $\mathrm{Ca}^{2+}$ ATPase pump ratio leads to contractile dysfunction. ${ }^{15}$ In vitro studies have revealed that higher phosphorylation levels of PLN lead to improved contractility, and that its dephosphorylation may promote heart failure. ${ }^{27}$ A specific PLN founder deletion mutation has been reported in patients with ARVC/D, indicating overlapping pathways between ARVC/D and DCM, and suggesting a role of PLN in the pathophysiology of ARVC/D. ${ }^{28}$ In our study, total PLN mRNA levels were significantly increased in our ARVC/D patients. Myocardial tissue in these patients displayed an increased protein signal intensity of total and phosphorylated PLN, whereas in controls and in DCM, total and especially phosphorylated PLN levels were much less. Increased total PLN at the mRNA level and increased phosphorylated PLN at the protein level are novel findings in patients with ARVC/D, who did not harbour a genetic PLN mutation. PLN and its phosphorylation status may likely contribute to the pathophysiology of $A R V C / D$, although the exact role of PLN remains to be identified. It could be hypothesized that increased PLN phosphorylation increasing myocardial contraction, could act as a compensatory mechanism for dysfunctional intercalated discs. This hypothesis has to be investigated in future studies. 


\section{Apoptosis and adipogenesis}

PERP, a proapoptotic molecule essential for p53-induced cell death, and with a recently described role in cell adhesion ${ }^{11}$, was also increased in ARVC/D in our study. PERP was upregulated on both mRNA and protein levels, independent of the underlying mutation in all patients. This upregulation underscores an important role of apoptosis in the failing right ventricular myocardium of patients with ARVC/D. ${ }^{23,29}$ As PERP is involved in cell adhesion, it could also be increased due to desmosomal malfunction, which is supported by the notion that other proapoptotic molecules were not significantly upregulated.

Moreover, we observed an increase of CPT1B mRNA and protein levels in our ARVC/D patients compared to DCM and controls, suggesting that this adipogenic factor may play a role in the pathophysiology of $A R V C / D$. It has been reported that alterations in transmembrane proteins and desmosomes may lead to changes in cell signalling, and to adipogenic/fibrogenic proliferation or an imbalance of fatty acid oxidation due to changes in PPAR molecules. ${ }^{30,31}$ In our study, we did not find a change in the mRNA expression of any PPAR molecule, but increased levels of the CPT1B molecule. Patient specific induced pluripotent stem cell studies revealed that co-activation of PPAR- $\alpha$ and $\gamma$ lead to CPT1B downregulation in an advanced-stage ARVC/D model. ${ }^{12}$ This in vitro study was based on severe PKP-2 mutations, and thus differs from our in vivo study in humans with variable desmosomal and non-desmosomal mutations. It may be speculated that CPT1B upregulation precedes downregulation in ARVC/D, as our ARVC/D patients generally did not display failing hearts. Furthermore, increased long chain fatty acid uptake into mitochondria may promote myocardial adipogenesis. Accordingly, studies have shown beneficial effects of inhibiting various steps of fatty acid oxidation in the progression of heart failure. ${ }^{32}$

\section{Genetic mutations}

In ARVC/D it is known that a radical mutation in desmosomal genes may be sufficient to yield the phenotype. Nonetheless, it has been reported that multiple variants can play a role as 
disease modifiers. ${ }^{33}$ Mutations in non-desmosomal genes represent a challenge in interpretation. Radical mutations in TTN have a higher likelihood to be disease causing, nevertheless several missense mutations in TTN have also been recognized as pathogenic. $^{34}$

Study limitations: The difficulty and safety aspects to obtain endomyocardial biopsies, myocardial explant and autopsy material from patients with this rare disease allowed access to a relatively low number of patients, particularly limiting subgroup analysis. Yet, subgroup analyses in patients with the same type of mutation in a wider range would be desirable in ARVC/D due to its high genetic heterogeneity. Furthermore, contamination with fibrous and endothelial tissue was present to some extent, although this was minimized through microscopic investigation. However, in spite of these limitations, we were able to show coherent and specific findings in myocardial tissue of patients with ARVC/D independent of underlying mutations.

\section{Conclusions}

This study demonstrates for the first time that PLN, PERP and CPT1B mRNA and protein expression is increased in right ventricular myocardial tissue of patients with ARVC/D compared to DCM and healthy controls, independent of the underlying genetic mutation. These results indicate that common pathophysiologic pathways involving sarcolemmal calcium channel regulation, apoptosis and adipogenesis may exist in this genetically heterogeneous disease.

\section{Acknowledgement}

We thank Prof. Dr. Guy Fontaine from the Institut de Cardiologie-Unité de Rhythmologie, La Salpêtrière Hospital Paris, for supporting this collaborative study, and Beate Rückert from the Swiss Institute of Allergy and Asthma Research Davos, for her expert technical advice. 


\section{Funding}

This study was funded by the Georg and Bertha Schwyzer-Winiker Foundation Zurich, Switzerland

\section{Conflicts of Interest}

There are no conflicts of interest related to this study.

Figure legends

Figure 1. Myocardial mRNA expression of molecules associated with cellular junctions in right ventricular myocardial tissue from patients with ARVC/D, DCM and healthy controls

A The expression of mRNAs coding for desmosomal proteins and gap junctions; B Expression of mRNAs coding for claudins; C Expression of mRNAs coding for molecules associated with cellular junctions.

ARVC/D n=10, DCM $n=10$, healthy controls $n=8$. Data are presented as $A U \pm S E M$, calculated as $\log \left(2^{(-\Delta \mathrm{ct})} \times 1000\right) .{ }^{*}=\mathrm{p}<0.05 ;{ }^{* *}=\mathrm{p}<0.01$

Figure 2. Myocardial mRNA expression of molecules involved in ion channels, cellular structures, apoptosis and adipogenesis in ARVC/D, DCM and healthy controls

A The expression of mRNAs coding for molecules involved in ion channels; B Expression of mRNAs coding for molecules involved in cellular structures; C Expression of mRNAs involved in apoptosis; D Expresison of mRNAs associated with adipogenesis ARVC/D $n=10, D C M n=10$, healthy controls $n=10$. Data are presented as $A U \pm S E M$, calculated as $\log \left(2^{(-\Delta c t)} \times 1000\right) .{ }^{*}=p<0.05 ;{ }^{* *}=p<0.01$ 
Figure 3. Analysis of ARVC/D patients with PKP-2 mutations

A PLN, PERP and CPT1B mRNA expression. ARVC/D with PKP-2 mutation $n=4, D C M$ $n=10$, healthy controls $n=8$ B PKP-2 mRNA expression in ARVC/D patients with PKP-2 mutations $(n=4)$ compared to ARVC/D patients without PKP2 mutations $(n=6) .{ }^{*}=p<0.05$; $* *=p<0.01$

C Representative immunohistochemistry of PKP-2. DAPI was used as nucleus staining. Number next to ARVC/D indicates patient number from Table 1B. Patients 8, 9, 10 are representatives for patients with PKP-2 mutation. D Quantitative analysis of relative protein signal intensity using Image $\mathrm{J}$ software. Patients with PKP-2 mutation are set as 1 , signal intensities of ARVC/D patients not harbouring a PKP-2 mutation are measured relatively. ARVC/D with PKP-2 mutation $n=4$, without PKP-2 mutation $n=6$; * $=p<0.05 ;{ }^{* *}=p<0.01$

Figure 4. Protein expression and distribution of PLN, PERP and CPT1B in the right ventricular myocardium of ARVC/D patients compared to DCM patients and healthy controls

A Representative immunohistochemistry of total and phosphorylated PLN, PERP and CPT1B. DAPI was used as nucleus staining. Number next to ARVC/D indicates patient number from Table 1B. Phosphorylation site of pPLN Ser16 and Thr 17 was detected.

B Quantitative analysis of relative protein signal intensity using Image $\mathrm{J}$ software. Control cardiac tissue is set as 1 , signal intensities were measured relatively compared to healthy controls. ARVC/D n=8, DCM n=5, controls $n=6 .{ }^{*}=p<0.05 ;{ }^{* *}=p<0.01$ 


\section{References}

1. Saguner AM, Duru F, Brunckhorst CB. Arrhythmogenic right ventricular cardiomyopathy: a challenging disease of the intercalated disc. Circulation 2013;128(12):1381-6.

2. Rampazzo A, Calore M, van Hengel J, van Roy F. Intercalated discs and arrhythmogenic cardiomyopathy. Circulation Cardiovascular genetics 2014;7(6):930-40.

3. van der Zwaag PA, Jongbloed JD, van den Berg MP, van der Smagt JJ, Jongbloed R, Bikker H, Hofstra RM, van Tintelen JP. A genetic variants database for arrhythmogenic right ventricular dysplasia/cardiomyopathy. Hum Mutat 2009;30(9):1278-83.

4. Groeneweg JA, Bhonsale A, James CA, et al.: Clinical Presentation, Long-Term Follow-Up, and Outcomes of 1001 Arrhythmogenic Right Ventricular Dysplasia/Cardiomyopathy Patients and Family Members. Circ Cardiovasc Genet 2015.

5. Schlipp A, Schinner C, Spindler V, Vielmuth F, Gehmlich K, Syrris P, Mckenna WJ, Dendorfer A, Hartlieb E, Waschke J. Desmoglein-2 interaction is crucial for cardiomyocyte cohesion and function. Cardiovasc Res 2014;104(2):245-57.

6. Agullo-Pascual E, Reid DA, Keegan S, Sidhu M, Fenyö D, Rothenberg E, Delmar M. Superresolution fluorescence microscopy of the cardiac connexome reveals plakophilin-2 inside the connexin43 plaque. Cardiovasc Res 2013;100(2):231-40.

7. Agullo-Pascual E, Cerrone M, Delmar M. Arrhythmogenic cardiomyopathy and Brugada syndrome: diseases of the connexome. FEBS Lett 2014;588(8):1322-30.

8. Agullo-Pascual E, Lin X, Leo-Macias A, et al.: Super-resolution imaging reveals that loss of the C-terminus of connexin43 limits microtubule plus-end capture and NaV1.5 localization at the intercalated disc. Cardiovasc Res 2014;104(2):371-81.

9. Basso C, Thiene G, Corrado D, Angelini A, Nava A, Valente M. Arrhythmogenic right ventricular cardiomyopathy. Dysplasia, dystrophy, or myocarditis? Circulation 1996;94(5):983-91.

10. Hariharan V, Asimaki A, Michaelson JE, Plovie E, MacRae CA, Saffitz JE, Huang $H$. Arrhythmogenic right ventricular cardiomyopathy mutations alter shear response without changes in cell-cell adhesion. Cardiovasc Res 2014;104(2):280-9. 
11. Franke WW, Heid H, Zimbelmann R, Kuhn C, Winter-Simanowski S, Dörflinger Y, Grund C, Rickelt S. Transmembrane protein PERP is a component of tessellate junctions and of other junctional and non-junctional plasma membrane regions in diverse epithelial and epitheliumderived cells. Cell Tissue Res 2013;353(1):99-115.

12. Kim C, Wong J, Wen J, et al.: Studying arrhythmogenic right ventricular dysplasia with patientspecific iPSCs. Nature 2013;494(7435):105-10.

13. Beffagna G, Occhi G, Nava A, Vitiello L, Ditadi A, Basso C, Bauce B, Carraro G, Thiene G, Towbin JA, Danieli GA, Rampazzo A. Regulatory mutations in transforming growth factor-beta3 gene cause arrhythmogenic right ventricular cardiomyopathy type 1. Cardiovasc Res 2005;65(2):366-73.

14. Sato PY, Musa H, Coombs W, Guerrero-Serna G, Patiño GA, Taffet SM, Isom LL, Delmar M. Loss of plakophilin-2 expression leads to decreased sodium current and slower conduction velocity in cultured cardiac myocytes. Circ Res 2009;105(6):523-6.

15. Haghighi K, Bidwell P, Kranias EG. Phospholamban interactome in cardiac contractility and survival: A new vision of an old friend. J Mol Cell Cardiol 2014;77:160-7.

16. Marcus FI, McKenna WJ, Sherrill D, et al.: Diagnosis of arrhythmogenic right ventricular cardiomyopathy/dysplasia: proposed modification of the Task Force Criteria. Eur Heart $\mathrm{J}$ 2010;31(7):806-14.

17. Hansen J, Lesnikova I, Funder AM, Banner J. Dna and rna analysis of blood and muscle from bodies with variable postmortem intervals. Forensic Sci Med Pathol. 2014;10:322-328

18. Ferrer I, Santpere G, Arzberger T, et al.: Brain protein preservation largely depends on the postmortem storage temperature: Implications for study of proteins in human neurologic diseases and management of brain banks: A brainnet europe study. J Neuropathol Exp Neurol. 2007;66:35-46

19. Gown AM, Willingham MC. Improved detection of apoptotic cells in archival paraffin sections: Immunohistochemistry using antibodies to cleaved caspase 3. J Histochem Cytochem. 2002;50:449-454

20. Collins FS, Hamburg MA. First FDA authorization for next-generation sequencer. N Engl J Med 2013;369(25):2369-71. 
21. Livak KJ, Schmittgen TD. Analysis of relative gene expression data using real-time quantitative PCR and the 2(-Delta Delta C(T)) Method. Methods 2001;25(4):402-8.

22. Wiesmann V, Franz D, Held C, Münzenmayer C, Palmisano R, Wittenberg T. Review of free software tools for image analysis of fluorescence cell micrographs. J Microsc. 2015;257:39-53

23. Campian ME, Tan HL, van Moerkerken AF, Tukkie R, van Eck-Smit BL, Verberne HJ. Imaging of programmed cell death in arrhythmogenic right ventricle cardiomyopathy/dysplasia. Eur $\mathrm{J}$ Nucl Med Mol Imaging 2011;38(8):1500-6.

24. Basso C, Czarnowska E, Della Barbera M, et al.: Ultrastructural evidence of intercalated disc remodelling in arrhythmogenic right ventricular cardiomyopathy: an electron microscopy investigation on endomyocardial biopsies. Eur Heart J 2006;27(15):1847-54.

25. Vite A, Gandjbakhch E, Prost C, et al.: Desmosomal cadherins are decreased in explanted arrhythmogenic right ventricular dysplasia/cardiomyopathy patient hearts. PLoS One 2013;8(9):e75082.

26. Rasmussen TB, Nissen PH, Palmfeldt $J$, et al.: Truncating plakophilin-2 mutations in arrhythmogenic cardiomyopathy are associated with protein haploinsufficiency in both myocardium and epidermis. Circ Cardiovasc Genet. 2014;7:230-240

27. del Monte F, Harding SE, Dec GW, Gwathmey JK, Hajjar RJ. Targeting phospholamban by gene transfer in human heart failure. Circulation 2002;105(8):904-7.

28. van der Zwaag PA, van Rijsingen IA, Asimaki A, et al.: Phospholamban R14del mutation in patients diagnosed with dilated cardiomyopathy or arrhythmogenic right ventricular cardiomyopathy: evidence supporting the concept of arrhythmogenic cardiomyopathy. Eur $\mathrm{J}$ Heart Fail 2012;14(11):1199-207.

29. Altin SE, Schulze PC. p53-upregulated modulator of apoptosis (PUMA): a novel proapoptotic molecule in the failing heart. Circulation 2011;124(1):7-8.

30. Lombardi R, da Graca Cabreira-Hansen M, Bell A, Fromm RR, Willerson JT, Marian AJ. Nuclear plakoglobin is essential for differentiation of cardiac progenitor cells to adipocytes in arrhythmogenic right ventricular cardiomyopathy. Circ Res 2011;109(12):1342-53. 
31. Djouadi F, Lecarpentier Y, Hébert JL, Charron P, Bastin J, Coirault C. A potential link between peroxisome proliferator-activated receptor signalling and the pathogenesis of arrhythmogenic right ventricular cardiomyopathy. Cardiovasc Res 2009;84(1):83-90.

32. Schreurs M, Kuipers F, van der Leij FR. Regulatory enzymes of mitochondrial beta-oxidation as targets for treatment of the metabolic syndrome. Obes Rev 2010;11(5):380-8.

33. Kapplinger JD, Landstrom AP, Salisbury BA, et al.: Distinguishing arrhythmogenic right ventricular cardiomyopathy/dysplasia-associated mutations from background genetic noise. J Am Coll Cardiol. 2011;57:2317-2327

34. Chauveau C, Rowell J, Ferreiro A. A rising titan: Ttn review and mutation update. Hum Mutat. 2014;35:1046-1059

\section{Clinical perspectives}

ARVC/D still remains a very challenging disease. The presence of many different causative genetic mutations and various involved cellular pathways makes patient characterization very difficult. Furthermore, a genetic cause cannot be identified in about $40 \%$ of patients despite modern genetic testing tools. In this study our aim was to investigate a broad range of candidate molecules in patients with a definite clinical diagnosis of ARVC/D, independent of the underlying genetic mutation. We measured mRNA levels of various junctional molecules, molecules involved in ion channels, cellular structures, apoptosis and adipogenesis. We compared right ventricular mRNA levels of ARVC/D patients with right ventricular cardiac tissue of healthy controls and of patients with non-familial dilated cardiomyopathy in order to identify specific mRNA patterns in ARVC/D. We describe, for the first time that mRNA levels of phospholamban, a key protein involved in the regulation of the sarcolemmal calcium channel, of PERP, a pro apoptotic molecule, and of CPT1B, a molecule being associated with adipogenesis, were all higher in ARVC/D patients. In addition, we observed that protein expression of these candidate molecules was also increased in ARVC/D patients with a different genetic background. These experimental results underscore that common pathophysiologic pathways exist, in this clinically and genetically heterogeneous disease. In 
clinical practice, ARVC/D diagnosis through characterization of myocardial biopsies still remains very difficult, and often leads to false negative results. Therefore, these novel markers could be used for improved tissue characterization and in the future, they may pave the way for targeted therapeutic applications.

Table 1A. ARVC/D and DCM patient characteristics

\begin{tabular}{|c|c|c|}
\hline Characteristics & ARVC/D & DCM \\
\hline Male, $n,(\%)$ & $10(100)$ & $10(100)$ \\
\hline $\begin{array}{l}\text { Family history / genetic } \\
\text { mutation, } n,(\%)\end{array}$ & $6(60)$ & $0(0)$ \\
\hline $\begin{array}{l}\text { Age at biopsy/HtTx, mean } \pm \\
\text { SD }\end{array}$ & $54 \pm 13$ & $49 \pm 14$ \\
\hline LV Involvment, n, (\%) & $4(40)$ & $10(100)$ \\
\hline LVEF\%, mean \pm SD & $53 \pm 10$ & $22 \pm 7$ \\
\hline
\end{tabular}

ARVC/D patients: $n=10$, DCM patients $n=10 ; \mathrm{HtTx}=$ heart transplantation; $L V=$ left ventricular; $L V E F=$ left ventricular ejection fraction 


\section{Table 1B. Individual ARVC/D patient characteristics}

\begin{tabular}{|c|c|c|c|c|c|c|c|c|}
\hline $\begin{array}{c}\text { ARVC/D } \\
\text { patient }\end{array}$ & Gender & $\begin{array}{l}\text { Major Criteria/ } \\
\text { Minor Criteria }\end{array}$ & TFS $^{*}$ & $\begin{array}{c}\text { Age at biopsy/ } \\
\text { HtTx }\end{array}$ & Family history & $\begin{array}{l}\text { Initial clinical } \\
\text { arrhythmias }\end{array}$ & RVFAC $\%$ & LVEF\% \\
\hline 1 & $\mathrm{~m}$ & $2 \mathrm{~A}, \mathrm{~B}, \mathrm{~F} / 1 \mathrm{C}$ & 7 & 61 & unknown & VF and SCA & 27 & 30 \\
\hline 2 & $\mathrm{~m}$ & $2 \mathrm{~A}, \mathrm{C}, \mathrm{D} / \mathrm{E}$ & 7 & 69 & unknown & $\begin{array}{l}\text { arrhythmogenic } \\
\text { syncope, nsVT with } \\
\text { LBBB morphology } \\
\text { and inferior axis }\end{array}$ & 17 & 57 \\
\hline 3 & $\mathrm{~m}$ & $2 \mathrm{~A}, \mathrm{E} / \mathrm{C}, \mathrm{D}$ & 7 & 53 & $\begin{array}{c}\text { Cousin with } S C D \text { at } \\
\text { age } 50\end{array}$ & $\begin{array}{l}\text { sVT with LBBB } \\
\text { morphology and } \\
\text { superior axis }\end{array}$ & 28 & 56 \\
\hline 4 & $\mathrm{~m}$ & $2 \mathrm{~A} / 1 \mathrm{C}, \mathrm{D}, \mathrm{E}$ & 5 & 46 & unknown & $\begin{array}{l}\text { sVT with LBBB } \\
\text { morphology and } \\
\text { superior axis }\end{array}$ & 33 & 55 \\
\hline 5 & $\mathrm{~m}$ & $2 \mathrm{~A}, \mathrm{~B} / \mathrm{E}, \mathrm{F}$ & 6 & 40 & $\begin{array}{c}\text { Mother with } \\
\text { probable ARVC/D } \\
(\mathrm{F})\end{array}$ & $\begin{array}{l}\text { sVT with LBBB } \\
\text { morphology and } \\
\text { superior axis }\end{array}$ & 20 & 50 \\
\hline 6 & $\mathrm{~m}$ & $2 A, D / 1 C, E$ & 6 & 54 & $\begin{array}{c}\text { Cousin with ICD at } \\
\text { age } 40\end{array}$ & $\begin{array}{l}\text { arrhythmogenic } \\
\text { syncope, nsVT with } \\
\text { LBBB morphology }\end{array}$ & 24 & 50 \\
\hline 7 & $\mathrm{~m}$ & $2 \mathrm{~A}, \mathrm{~F} / \mathrm{E}$ & 5 & 26 & $\begin{array}{l}\text { Mother with SCD, } \\
\text { severe ARVC/D (F) }\end{array}$ & $\begin{array}{l}\text { arrhythmogenic } \\
\text { syncope >500VES } \\
\text { per } 24 \text { hours }(E)\end{array}$ & 25 & 60 \\
\hline 8 & $\mathrm{~m}$ & $2 A, D, F / 1 C, E$ & 8 & 62 & $\begin{array}{l}\text { confirmed ARVC/D } \\
\text { in first-degree } \\
\text { relative }(F)\end{array}$ & $\begin{array}{l}\text { sVT with LBBB } \\
\text { morphology }\end{array}$ & NA & 57 \\
\hline 9 & $\mathrm{~m}$ & $2 A, C, E, F$ & 8 & 65 & unknown & $\begin{array}{l}\text { sVT with LBBB } \\
\text { morphology }\end{array}$ & NA & 65 \\
\hline 10 & $\mathrm{~m}$ & $2 \mathrm{~A}, \mathrm{~F}$ & 4 & 60 & Uncle with SCD & VF & NA & 45 \\
\hline
\end{tabular}

$\mathrm{HtTx}=$ heart transplantation; ICD= implantable cardioverter-defibrillator; LBBB= left bundle branch block; LVEF= left ventricular ejection fraction; RVOT= right ventricular outflow tract; SAECG= signal-averaged ECG; SCA= sudden cardiac arrest; VF= ventricular fibrillation; sVT= sustained ventricular tachycardia; nsVT= nonsustained ventricular tachycardia;

TFS = task force score, *adapted from Task force criteria according to Marcus et $\mathrm{al}^{15}$ with each major criterion counting as two points and each minor criterion as one point, at least four points required for definite diagnosis; diagnostic categories; $A=$ global or regional dysfunction with structural alterations; $B=$ tissue characterization; $C=$ repolarization abnormalities; $\mathrm{D}=$ depolarization abnormalities; $\mathrm{E}=$ arrhythmias; $\mathrm{F}=$ family history. 
Table 2. Genetic mutations of ARVC/D patients

\begin{tabular}{|c|c|c|c|c|c|c|c|c|}
\hline Patient & Gene & $\begin{array}{c}\text { DNA } \\
\text { change }\end{array}$ & $\begin{array}{l}\text { Protein } \\
\text { change }\end{array}$ & Type & Transcript & SIFT & Polyphen 2 & $\begin{array}{c}\text { Mutation } \\
\text { Tester }\end{array}$ \\
\hline 1 & DSP & c. $4531 \mathrm{G}>\mathrm{T}$ & p.GIn $1511^{*}$ & Nonsense & NM_004415.2 & NA & NA & $\begin{array}{l}\text { Disease } \\
\text { Causing }\end{array}$ \\
\hline 2 & DSP & c. $4609 \mathrm{C}>\mathrm{T}$ & p.Arg1537Cys & Missense & NM_004415.2 & Tolerated & $\begin{array}{l}\text { Possibly } \\
\text { Damaging }\end{array}$ & VUS \\
\hline \multirow[b]{2}{*}{3} & DSP & c. $88 \mathrm{G}>\mathrm{A}$ & p.Val30Met & Missense & NM_004415.2 & Tolerated & Benign & $\begin{array}{l}\text { Disease } \\
\text { Causing }\end{array}$ \\
\hline & DSG-2 & c. $877 A>G$ & p.lle293Val & Missense & NM_001943.3 & $\begin{array}{l}\text { Affects } \\
\text { protein } \\
\text { function }\end{array}$ & $\begin{array}{l}\text { Possibly } \\
\text { Damaging }\end{array}$ & Polymorphism \\
\hline 5 & TTN & c. $99872 \mathrm{~T}>\mathrm{C}$ & Met33291Thr & Missense & NM_133378.4 & $\begin{array}{l}\text { Affects } \\
\text { protein } \\
\text { function }\end{array}$ & VUS & VUS \\
\hline 6 & RYR-2 & c. $12917 \mathrm{~T}>\mathrm{C}$ & p.Phe4306Ser & Missense & NM_001035.2 & Tolerated & VUS & VUS \\
\hline \multirow{2}{*}{7} & PKP-2 & c. $2392 A>G$ & p.Thr798ArG & Missense & NM_004572.3 & $\begin{array}{l}\text { Affects } \\
\text { protein } \\
\text { function }\end{array}$ & $\begin{array}{l}\text { Possibly } \\
\text { Damaging }\end{array}$ & $\begin{array}{l}\text { Disease } \\
\text { Causing }\end{array}$ \\
\hline & DSG-2 & c. $877 A>G$ & p.lle293Val & Missense & NM_001943.3 & $\begin{array}{l}\text { Affects } \\
\text { protein } \\
\text { function }\end{array}$ & $\begin{array}{l}\text { Possibly } \\
\text { Damaging }\end{array}$ & Polymorphism \\
\hline 8 & PKP-2 & c. $2176 \mathrm{C}>\mathrm{T}$ & p.GLn726X & Nonsense & NM_004572.3 & NA & NA & $\begin{array}{l}\text { Disease } \\
\text { Causing }\end{array}$ \\
\hline 9 & PKP-2 & c. 1803 delC & p.D601EfsX655 & $\begin{array}{l}\text { Deletion; } \\
\text { Frameshift }\end{array}$ & NM_004572.3 & NA & NA & $\begin{array}{l}\text { Disease } \\
\text { causing }\end{array}$ \\
\hline 10 & PKP-2 & c. $658 \mathrm{C}>\mathrm{T}$ & p.GLn220X & Nonsense & NM_004572.3 & NA & NA & $\begin{array}{l}\text { Disease } \\
\text { Causing }\end{array}$ \\
\hline
\end{tabular}

$\mathrm{NA}=$ not available; ${ }^{*} \mathrm{NM}=$ human genome variation society number; VUS=variant of unknown significance; SIFT, Polyphen 2 and Mutation Taster are databases that predict the pathogenic effect of a variant; Patient 4 did not have any ARVC/D associated genetic mutation.

Table 3A. mRNA levels of candidate molecules of all ARVC/D patients, DCM patients and healthy controls in arbitrary units (AU)

$\begin{array}{ccccccc} & \text { ARVC/D } & \text { DCM } & \text { Control } & \text { p-value } & \text { p-value } & \text { p-value } \\ \text { mRNA } & \text { AU } & \text { AU } & \text { AU } & \begin{array}{c}\text { ARVC/D } \\ \text { versus DCM }\end{array} & \begin{array}{c}\text { ARVC/D } \\ \text { versus control }\end{array} & \begin{array}{c}\text { control versus } \\ \text { DCM }\end{array} \\ & \text { mean } \pm \text { SEM } & \text { mean } \pm \text { SEM } & \text { mean } \pm \text { SEM } & & & 0.76 \\ \text { PLN } & 1626.2 \pm 351.7 & 216.2 \pm 62.8 & 175.3 \pm 44.8 & <0.001 & <0.001 & 0.18 \\ \text { PERP } & 26.9 \pm 5.6 & 10.8 \pm 2.7 & 6.8 \pm 2.1 & 0.001 & <0.001 & \\ \text { CPT1B } & 22.2 \pm 12.5 & 1.8 \pm 0.3 & 2.8 \pm 1.3 & <0.001 & 0.008 & 0.9\end{array}$

Statistical significance was assumed for $p$ values $<0.05$. Data are presented as $A U \pm S E M$, calculated as $2^{(-\Delta c t)} \times$ 1000 .

ARVC/D n=10, DCM n=10, Control $n=8$ 
Table 3B. mRNA levels of candidate molecules of ARVC/D patients with PKP-2 mutation, DCM patients and healthy controls in arbitrary units (AU)

\begin{tabular}{|c|c|c|c|c|c|c|}
\hline \multirow{3}{*}{ mRNA } & $\begin{array}{c}\text { ARVC/D with PKP- } \\
2 \text { mutation }\end{array}$ & DCM & Control & $\mathrm{p}$-value & \multirow{3}{*}{$\begin{array}{l}\text { p-value } \\
\text { ARVC/D } \\
\text { versus } \\
\text { control }\end{array}$} & \multirow{3}{*}{$\begin{array}{c}\text { p-value } \\
\text { control } \\
\text { versus DCM }\end{array}$} \\
\hline & $A U$ & $A U$ & $\mathrm{AU}$ & $\begin{array}{c}\text { ARVC/D } \\
\text { versus DCM }\end{array}$ & & \\
\hline & mean \pm SEM & mean \pm SEM & mean \pm SEM & & & \\
\hline PLN & $988.2 \pm 250.7$ & $216.2 \pm 62.8$ & $175.3 \pm 44.8$ & 0.008 & 0.004 & 0.76 \\
\hline PERP & $22.6 \pm 2.0$ & $10.8 \pm 2.7$ & $6.8 \pm 2.1$ & 0.008 & 0.01 & 0.18 \\
\hline CPT1B & $6.0 \pm 2.2$ & $1.8 \pm 0.3$ & $2.8 \pm 1.3$ & 0.02 & 0.15 & 0.9 \\
\hline
\end{tabular}

Statistical significance was assumed for $p$ values $<0.05$. Data are presented as AU \pm SEM, calculated as $2^{(-\Delta c t)} \times$ 1000. ARVC/D patients with pathogenic PKP-2 mutation $n=4, D C M=10$, Control $n=8$ 


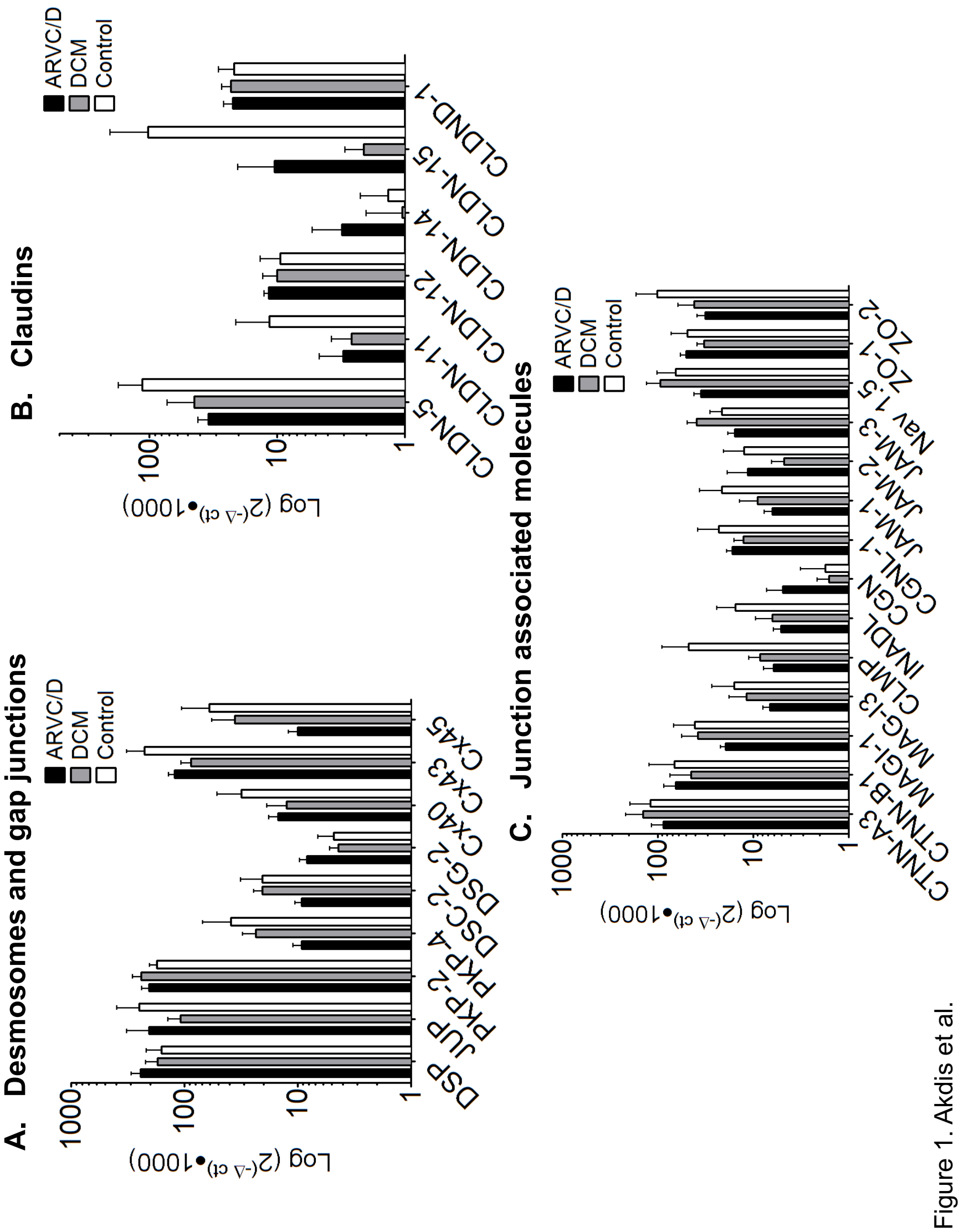



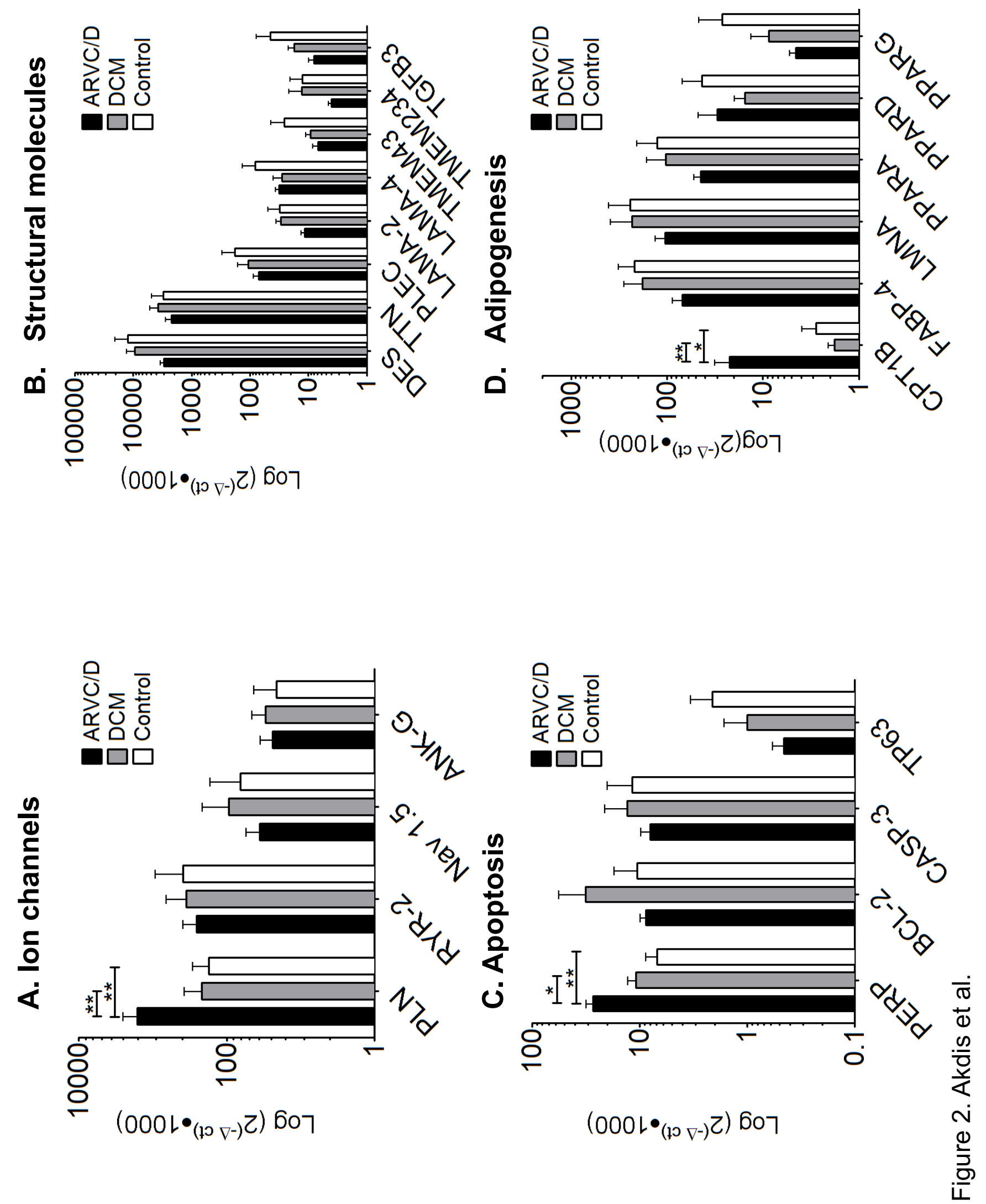
동
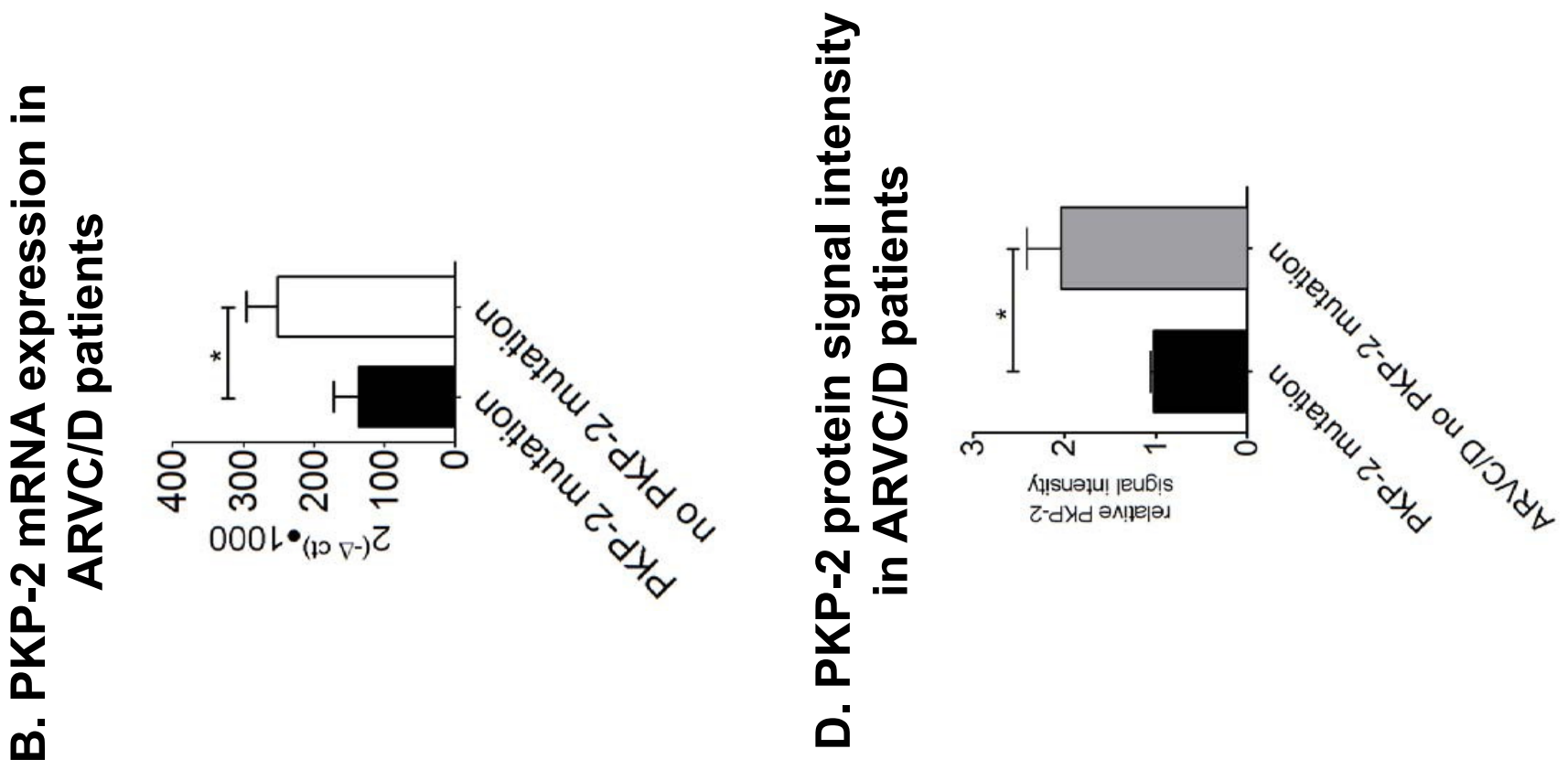

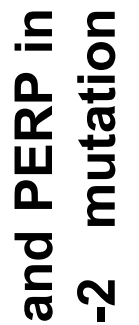

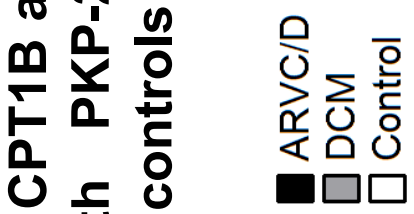

Z

幽

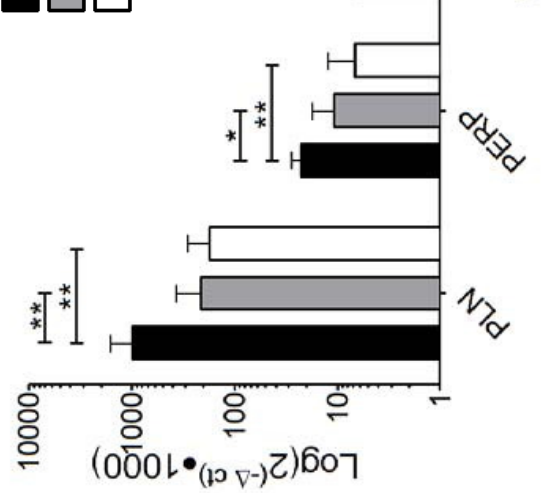

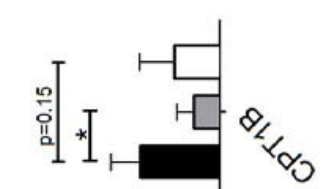
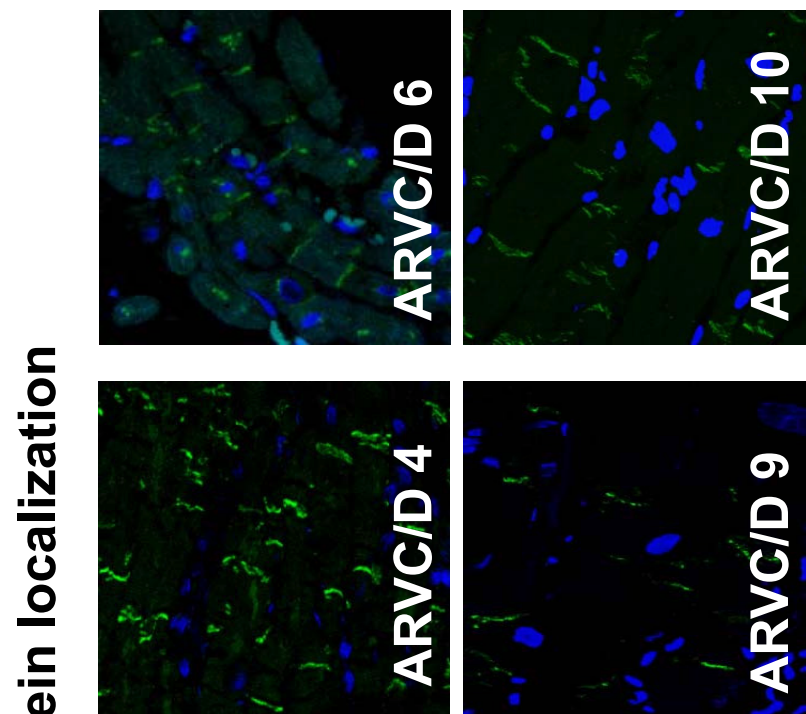

ᄃ음

을

응 은

\&

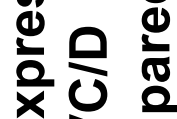

uํㅡㄹ

$<\frac{\alpha}{4}$

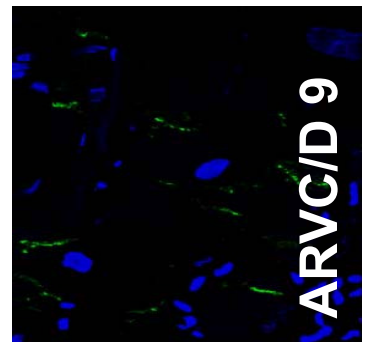

$\bar{\sigma}$

ง

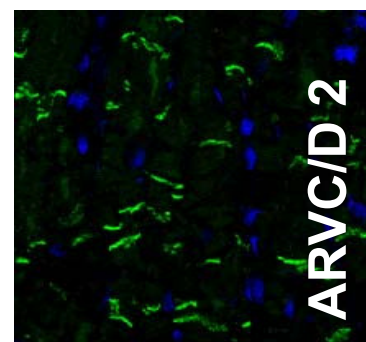

$\pm$

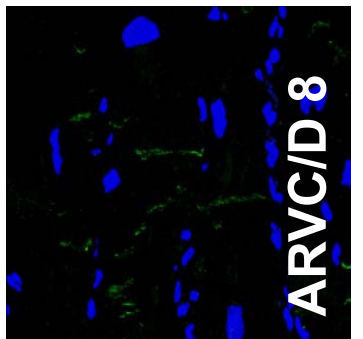

옹

$\frac{n}{2}$

D

()

$\stackrel{\varrho}{=}$

j

i몬 

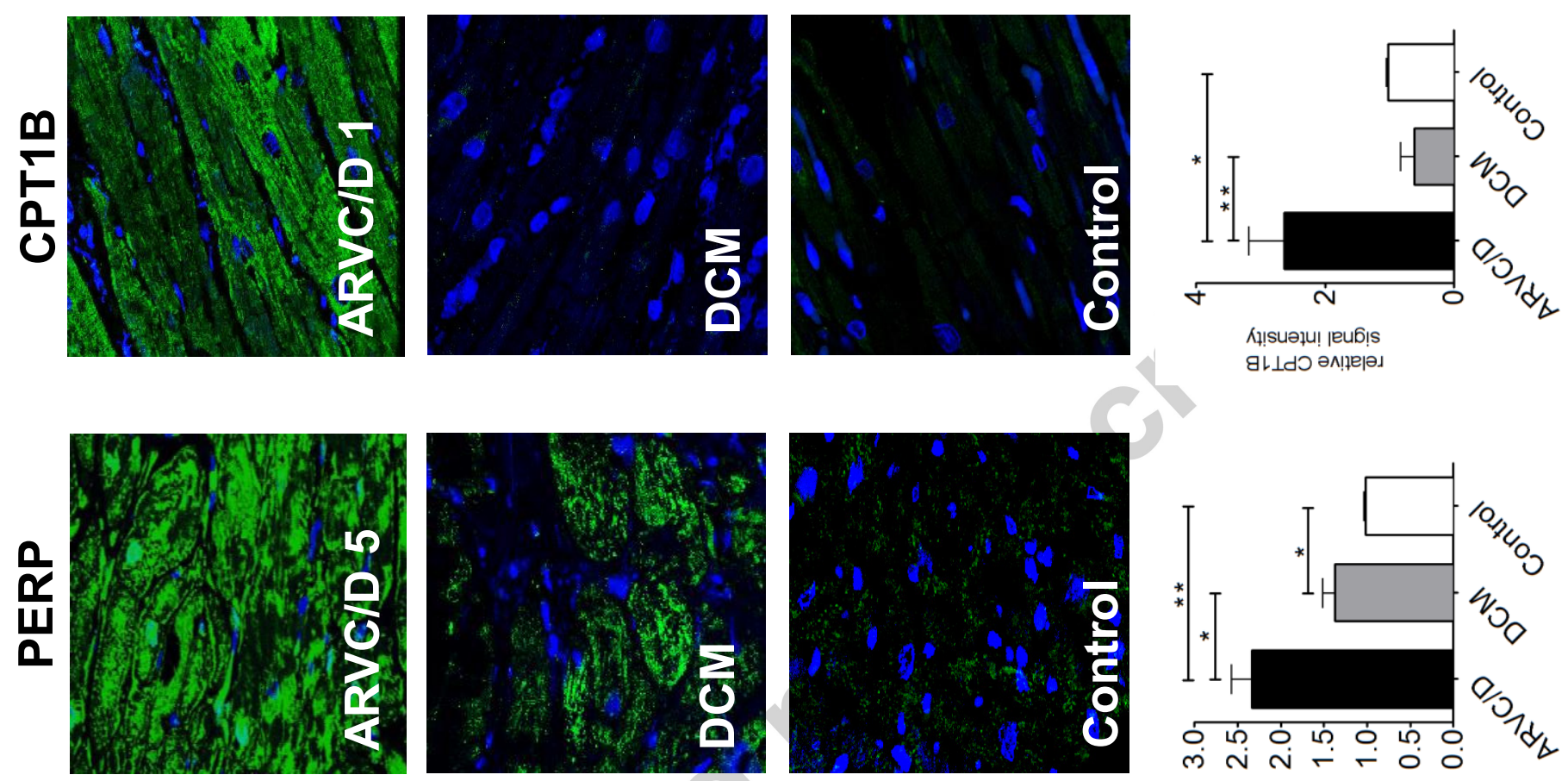

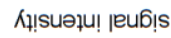
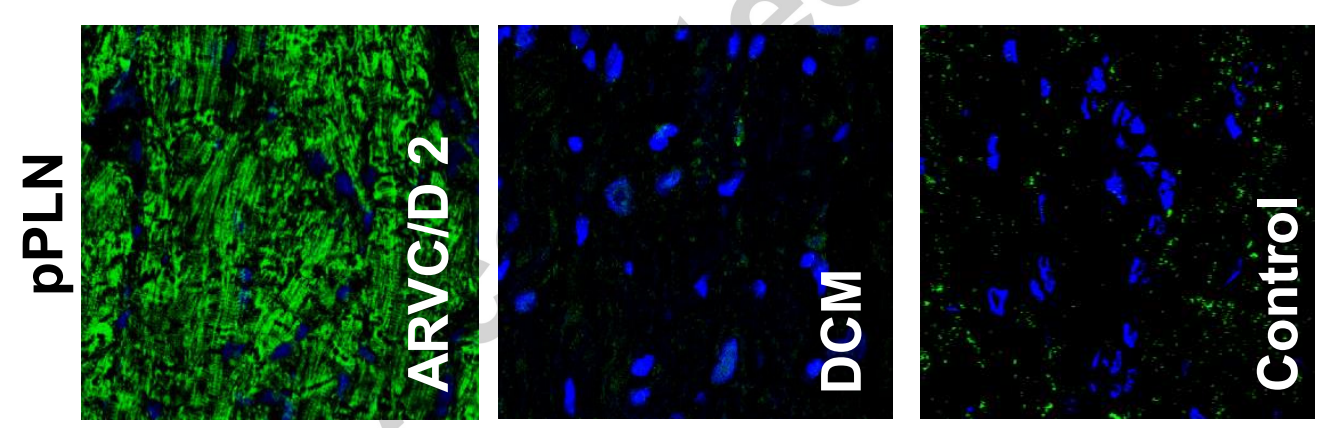

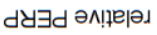
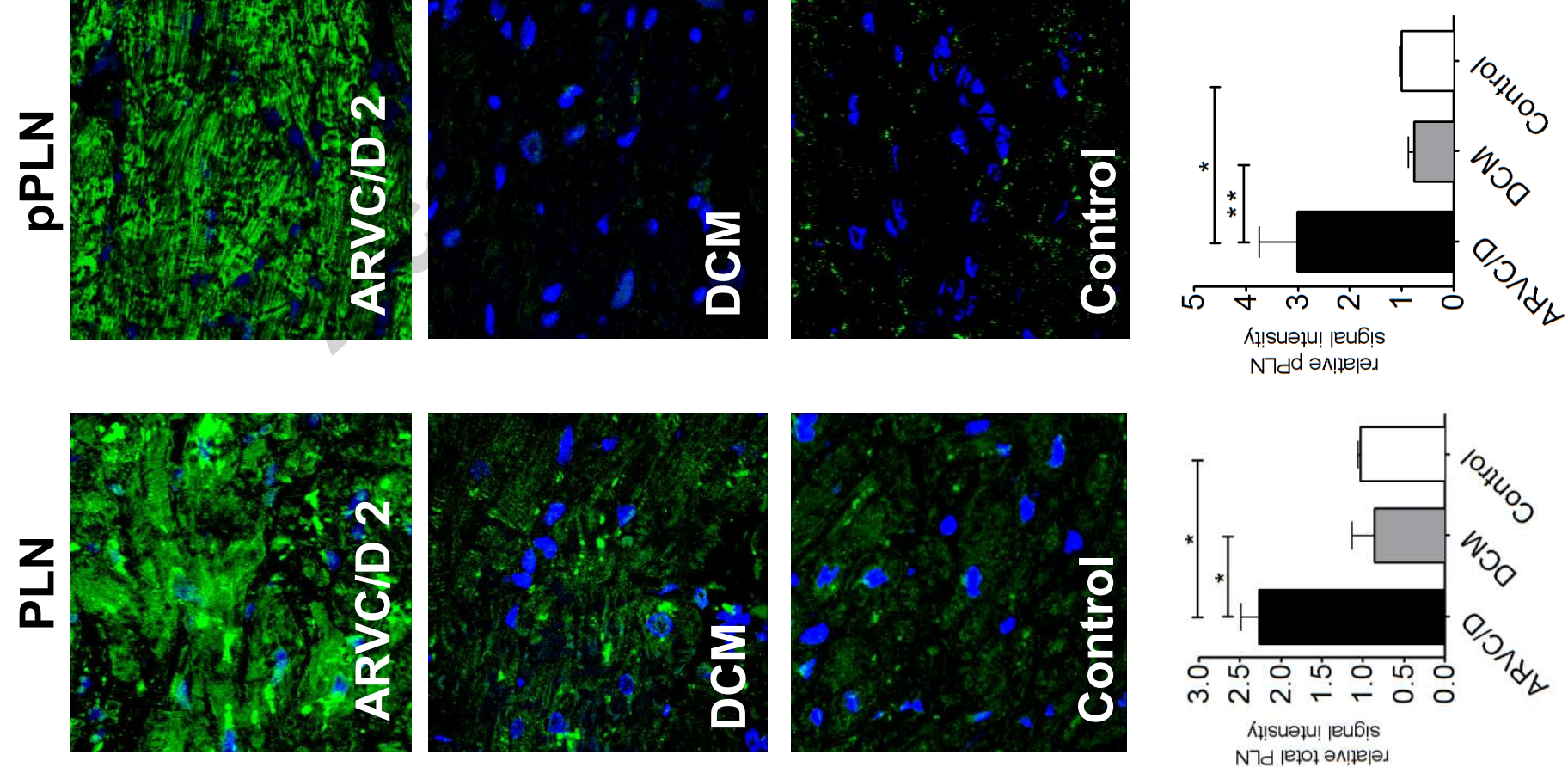

Nרdd әN!̣E|əג

高

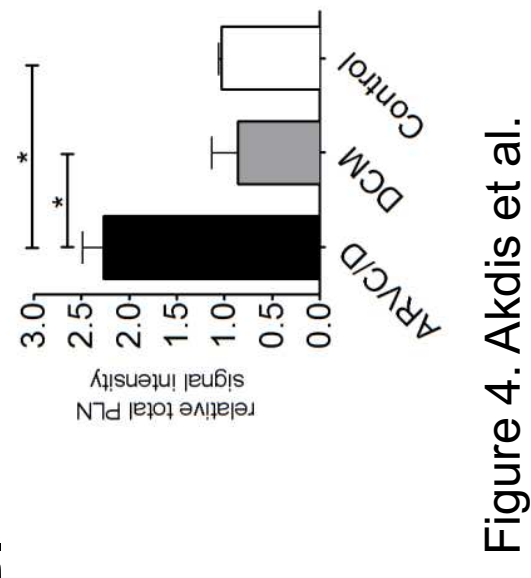

